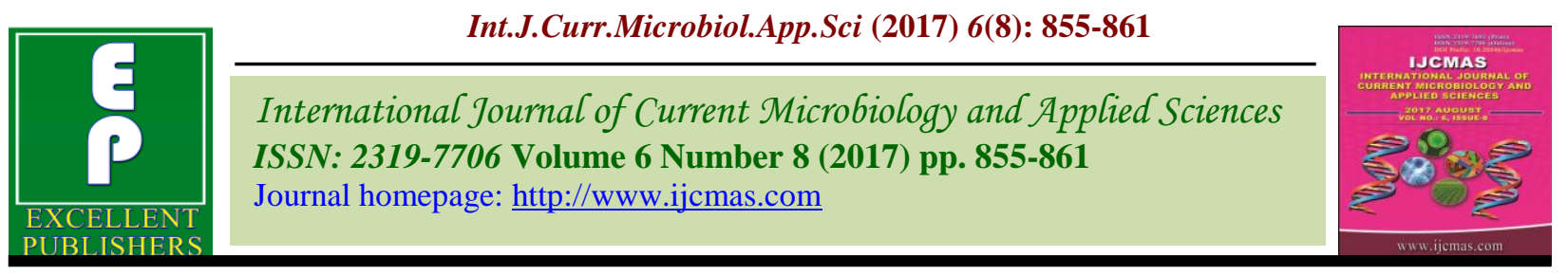

Original Research Article https://doi.org/10.20546/ijcmas.2017.608.108

\title{
GPS-GIS Based Soil Maps of Micronutrients Status in Organic Farms at College of Agriculture, Pune (M.S.), India
}

\author{
Vivekananda Aich $^{1}$, N.B. More ${ }^{1}$, Shiva Kumar Udayana ${ }^{2 *}$ and G.D. Patil ${ }^{1}$ \\ ${ }^{1}$ Division of Soil Science and Agricultural Chemistry, College of Agriculture, Pune, 411005, \\ Maharashtra, India \\ ${ }^{2}$ Department of Agricultural Chemistry and Soil science, Bidhan Chandra Krishi \\ Viswavidyalaya, Mohanpur, Nadia, West Bengal-741252, India \\ *Corresponding author
}

A B S T R A C T

\begin{tabular}{l} 
K e y w or d s \\
Organic farm, \\
Spatial \\
distribution, GPS, \\
GIS, \\
Micronutrient \\
maps and \\
Correlation \\
coefficient. \\
Article Info \\
\hline $\begin{array}{l}\text { Accepted: } \\
\text { xx June } 2017 \\
\text { Available Online: } \\
\text { xx August } 2017\end{array}$ \\
\hline
\end{tabular}

\section{Introduction}

The initiation of newly developed tools like Global Positioning System (GPS), Geographical Information System (GIS), which helps in generating the spatial thematic maps about the distribution of nutrients (Sharma, 2004), the maps generated through global positioning system (GPS) and geographical information system (GIS) helps in delineating the homogeneous units to decide on the sampling size and thereby saving a lot of problems. This also helps to monitor the changes in nutrient status over a period of time as geo referenced sampling side can be revisited with the help of GPS which is otherwise difficult in random sampling (Sood et al., 2004). The maps can also be useful for guiding the farmers to decide the amount of micronutrient fertilizers for optimum/economic returns areas having deficiency of one or more nutrients than those having sufficient nutrients. The imbalance use of micronutrient fertilizers over a period of time can be minimized by using soil fertility maps. The GPS-GIS technique has great 
significance in agriculture for future monitoring of soil nutrient status of different locations/villages. This technique is also useful for fulfilling the demand and supply of food commodities by judging the fertility status of different soils of study area. The data can be utilized for maintaining and building the fertility status of soils by balanced use of organic and inorganic fertilizers. The site specific nutrient management can be judged by adopting this technique. However, the information on iron, manganese, zinc copper and boron status and correlation with chemical properties of soils in Organic Farm at College of Agriculture, Pune on GPS is scanty in literature. Hence, the present investigation was undertaken to generate a fertility maps in respect to micronutrient status of organic farms.

\section{Materials and Methods}

The geo-referenced surface $(0-20 \mathrm{~cm})$ soil samples (125) were collected from organic farm, College of Agriculture, Pune at an interval of $50 \mathrm{~m}$ grid (Figure 1) with the help of hand held global Positioning system (GPS) version 9.3. Then soil samples were brought to the laboratory and air dried under shade avoiding contamination with foreign/iron materials and then crushed with a wooden pestle and mortar. The samples are then screened through a $2 \mathrm{~mm}$ sieve and the pebbles, stones and roots were rejected. The analysis of soil samples with respect to chemical properties have been carried out by using standard methods as described in Page et al., (1982). Available micronutrients (Fe, $\mathrm{Mn}, \mathrm{Zn}$, and $\mathrm{Cu}$ ) by DTPA extractable method (Lindsay and Norwell, 1978) and available B (Bingham 1982) were used for estimation.

\section{Generation of maps}

The revenue map of organic farm of college was digitized. The Arc catalogue software, the columns for available $\mathrm{Fe}, \mathrm{Mn}, \mathrm{Zn}, \mathrm{Cu}$ and $B$ were added in the layer to enter the attribute data. The available data were imported from MS-Excel and assigned to polygon attribute table in the layer. From the attribute data base, different thematic layers were reclassified to generate various thematic maps on available nutrients of $\mathrm{N}, \mathrm{P}$ and $\mathrm{K}$ values. The suitable annotations like legend, North arrow and scale were composed on thematic maps. The thematic maps of available Fe, Mn, $\mathrm{Zn}, \mathrm{Cu}$, and $\mathrm{B}$ are generated and presented. The samples were analyzed for micronutrient status an prepared thematic map by using of Arc GIS 9.3 version.

\section{Results and Discussion}

\section{Chemical properties}

The $\mathrm{pH}$ of the soils ranges from 7.45 to 8.06 (Table 1) with mean value of 7.91. Among the soil samples tested, most of the soils were slightly alkaline $(78.40 \%)$ followed by moderately alkaline $(21.60 \%)$. The very less variation in soil $\mathrm{pH}$ may be due to the inherent homogeneity occurrence of black soils within the organic block and specific cultural and fertilizer management practices to be fallowed. The similar types of observations were also recorded by Katariya (2011) in soil collected from the Water Management Project-Block A, Central Campus, MPKV, Rahuri. Most of the samples were slightly alkaline in nature. this might be due to soils are sloppy, shallow, well drained and light in colour and rest samples are moderately alkaline due to deep to medium black soils being under irrigation since long have shifted to alkaline condition (Yadav, 2002). The electrical conductivity of various soil samples of organic farm were ranges from 0.18 to $0.43 \mathrm{dS} \mathrm{m} \mathrm{m}^{-1}$ with mean value of $0.31 \mathrm{dS} \mathrm{m}^{-1}$. The results indicated that all the soils are normal in nature and suitable for all types of crops and for healthy plant growth due to the soils are free from salinity. The 
similar results were also reviewed by Padole and Mahajan (2003) in swell-shrink soils of Vidharbha region. The organic carbon content ranges from 2.9 to $9.6 \mathrm{~g} \mathrm{~kg}^{-1}$ with the mean of $6.1 \mathrm{~g} \mathrm{~kg}^{-1}$. In general, 46.4 per cent soils were moderate and 40.8 per cent soils were moderately high in organic carbon content. Out of total cultivated area of the organic farm, 9.6 per cent of the area comes in high organic carbon content, 46.40 per cent are moderate, 40.80 per cent are moderately high and 3.2 per cent are low organic carbon content. Moderate and moderately high content of organic carbon was observed which might be because of addition of organic matter into the soil. The wide variation in organic carbon content in the tested soil might be because of decomposition rate of substrate and different vegetable crops to be grown in the organic farms. The similar types of result were also reported by Meena (2009) in Central Research Farm of MPKV, Rahuri, Maharashtra and Yeresheemi et al., (1997) in salt affected soils of Krishna Command of Karnataka. The calcium carbonate ranged from the 5.0 to 10.75 per cent with an average of 6.59 per cent. The 80 per cent soils were found in moderately high calcium carbonate content, while 16.8 per cent in moderate followed by 3.2 per cent soils were in very high calcium carbonate content.

\section{Micronutrient status of soils}

The available iron in soils of organic farm of College of Agriculture, Pune was ranged from 5.96 to $11.70 \mathrm{mg} \mathrm{kg}^{-1}$ with an average of 9.52 $\mathrm{mg} \mathrm{kg}{ }^{-1}$ (Table 2 and Fig. 2). All the soil samples collected from organic farm were sufficient in available iron, as the critical limit of available iron is $4.5 \mathrm{mg} \mathrm{kg}^{-1}$ (Takkar et al., 1989). The similar trend of Fe was noted by Meena (2009) in Central Research Farm MPKV, Rahuri for different Inceptisols of Maharashtra. The sufficiency of available iron might be due to high organic matter content whereas deficiency might be due to excess of phosphorus in soil. The available manganese in soils of organic farm was ranged from 5.62 to $16.68 \mathrm{mg} \mathrm{kg}^{-1}$ with an average of $11.83 \mathrm{mg}$ $\mathrm{kg}^{-1}$ (Table 2 and Fig. 3). All the soil samples collected from organic farm were sufficient in available manganese, as the critical limit of available manganese is $2 \mathrm{mg} \mathrm{kg}^{-1}$ (Takkar et al., 1989).

Table.1 Chemical properties of soils in organic farm, College at Agriculture, Pune

\begin{tabular}{|c|c|c|c|c|}
\hline Particular & pH (1:2.5) & $\mathrm{EC}\left(\mathrm{dS} \mathrm{m}^{-1}\right)$ & $\mathrm{OC}\left(\mathrm{g} \mathrm{kg}^{-1}\right)$ & $\mathrm{CaCO}_{3}(\%)$ \\
\hline Mean & 7.91 & 0.31 & 6.1 & 6.59 \\
\hline Range & $7.45-8.06$ & $0.18-0.43$ & $2.9-9.6$ & $5.0-10.75$ \\
\hline Category & $\begin{array}{c}\text { Slightly alkaline } \\
(78.40)^{*} \\
\text { Moderately alkaline } \\
\text { (21.60) }\end{array}$ & $\begin{array}{c}\text { Normal } \\
(100)\end{array}$ & $\begin{array}{c}\text { Low } \\
(3.20) \\
\text { Moderate } \\
(46.40) \\
\text { Moderately } \\
\text { high (40.80) } \\
\text { High } \\
(9.60) \\
\end{array}$ & $\begin{array}{l}\text { Moderate (16.80) } \\
\text { Moderately high } \\
\quad(80.80) \\
\text { Very high }(3.20)\end{array}$ \\
\hline $\mathrm{SE} \pm$ & 0.013 & 0.259 & 0.011 & 0.140 \\
\hline
\end{tabular}

(* Figures in parenthesis indicate per cent value) 
Table.2 Micronutrient status of soils $\left(\mathrm{kg} \mathrm{ha}^{-1}\right)$ in organic farm, at College of Agriculture, Pune

\begin{tabular}{|c|c|c|c|c|c|}
\hline \multirow{2}{*}{ Particular } & \multicolumn{5}{|c|}{ DTPA extractable micronutrients $\mathbf{~ m g ~ k g ~}^{-1}$ ) } \\
\cline { 2 - 6 } & $\mathbf{F e}$ & $\mathbf{M n}$ & $\mathbf{C u}$ & $\mathbf{Z n}$ & $\mathbf{B}$ \\
\hline Mean & 9.52 & 11.83 & 5.82 & 1.93 & 0.49 \\
\hline Range & $5.96-11.70$ & $5.62-16.68$ & $3.36-7.64$ & $1.06-3.68$ & $0.33-0.69$ \\
\hline Category & $\begin{array}{c}\text { Sufficient } \\
(100)\end{array}$ & $\begin{array}{c}\text { Sufficient } \\
(100)\end{array}$ & $\begin{array}{c}\text { Sufficient } \\
(100)\end{array}$ & $\begin{array}{c}\text { Sufficient } \\
(100)\end{array}$ & $\begin{array}{c}\text { Deficient } \\
(56.00)\end{array}$ \\
& & & & & $\begin{array}{c}\text { Sufficient } \\
(44.00)\end{array}$ \\
& & & & & 0.046 \\
\hline SE \pm & 0.115 & 0.206 & 0.092 & 007 \\
\hline
\end{tabular}

(Total No. of soil samples analysized-125, figures in parenthesis is in per cent)

Table.3 Correlation coefficient between chemical properties and available nutrients in soil of organic farm of College of Agriculture, Pune

\begin{tabular}{|c|c|c|c|c|}
\hline Micronutrients & pH & EC & O.C & $\mathbf{C a C O}_{3}$ \\
\hline $\mathrm{Fe}$ & -0.007 & -0.110 & -0.032 & $-0.170^{* *}$ \\
\hline $\mathrm{Mn}$ & -0.008 & $-0.328^{*}$ & 0.131 & $-0.244^{*}$ \\
\hline $\mathrm{Cu}$ & 0.030 & -0.137 & 0.043 & -0.110 \\
\hline $\mathrm{Zn}$ & 0.083 & -0.101 & 0.062 & -0.066 \\
\hline $\mathrm{B}$ & -0.064 & -0.018 & -0.078 & -0.031 \\
\hline
\end{tabular}

* Significant at $5 \%$ level-0.1946

** Significant at $1 \%$ level- 0.1636

Fig.1 Location map of organic farm, A.C, Pune

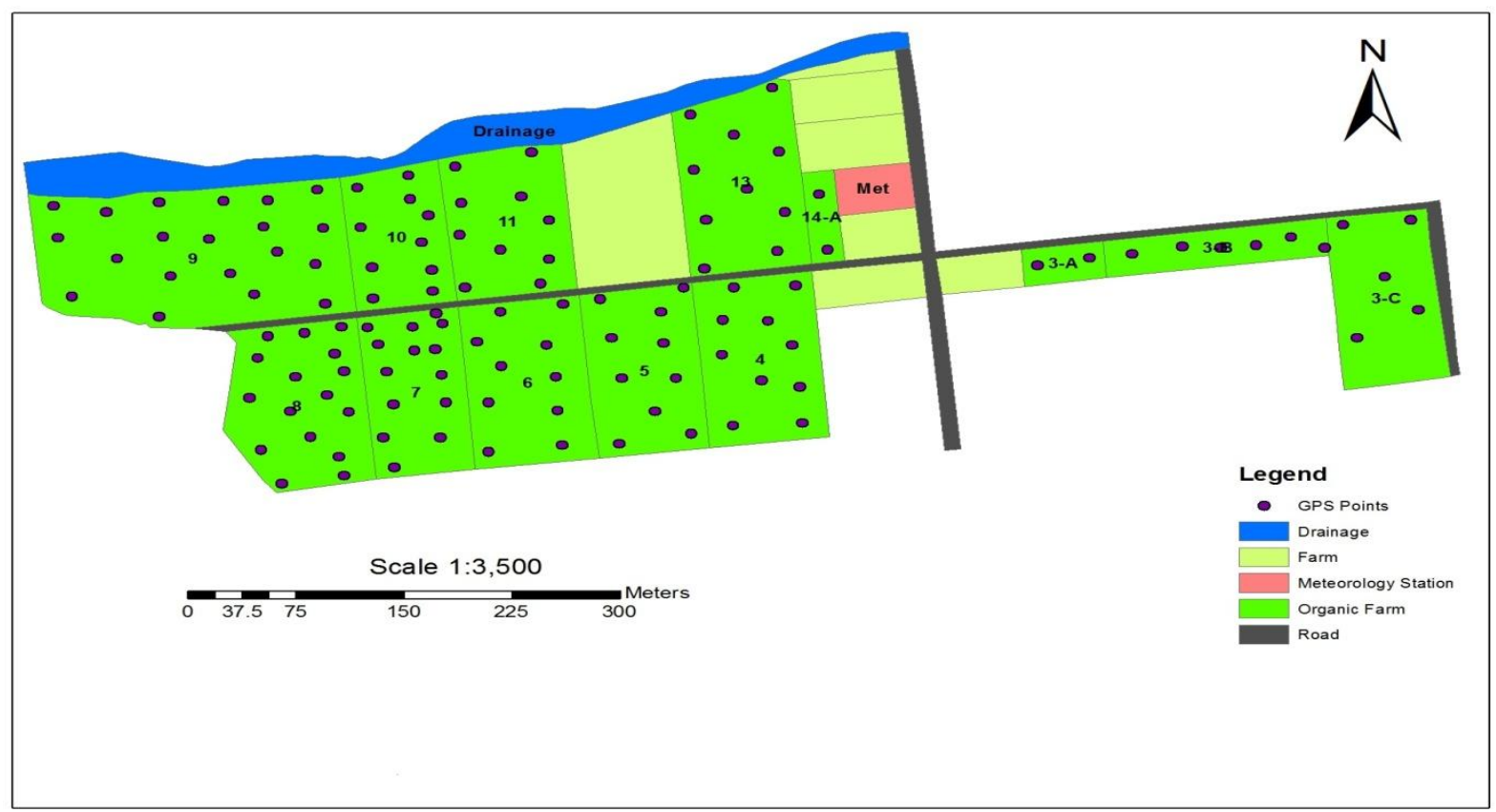


Fig.2\&3 GPS based soil available Fe map and GPS based soil available Mn map
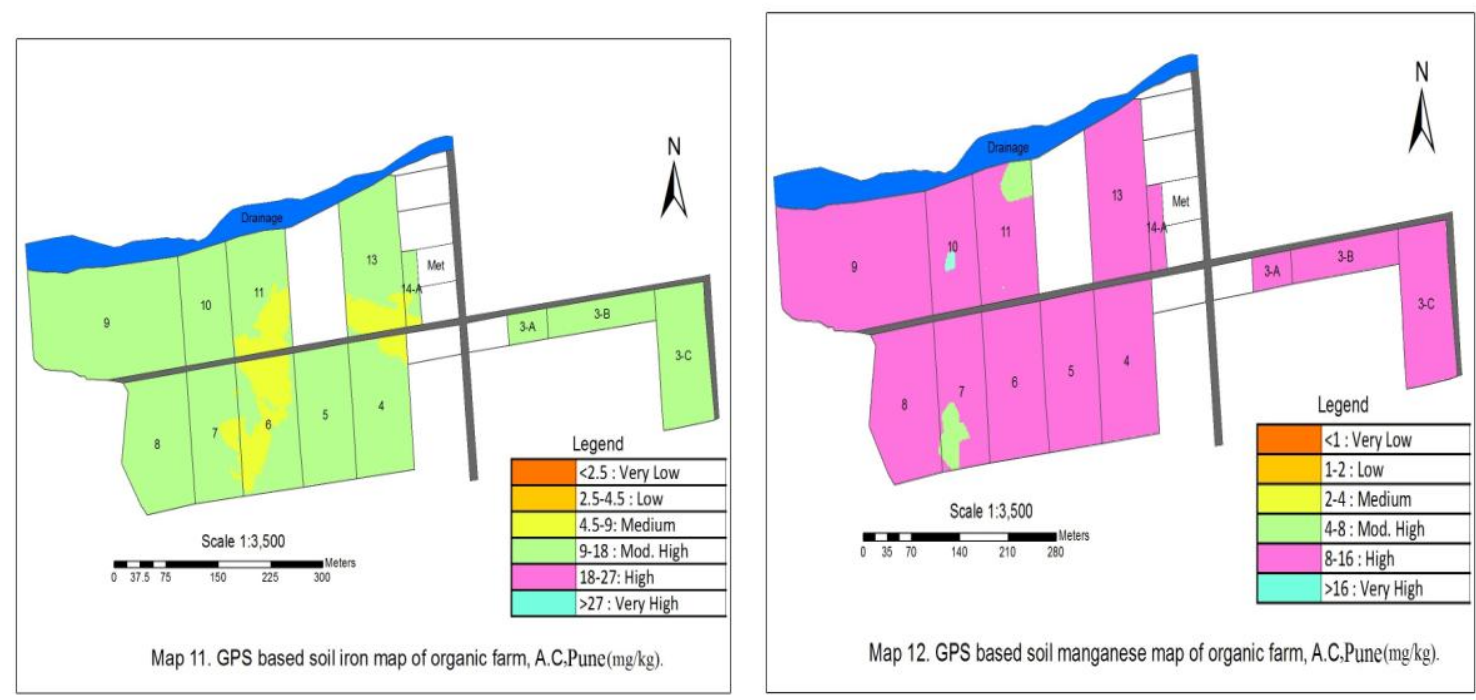

Fig.4 GPS based soil available $\mathrm{Cu}$ map

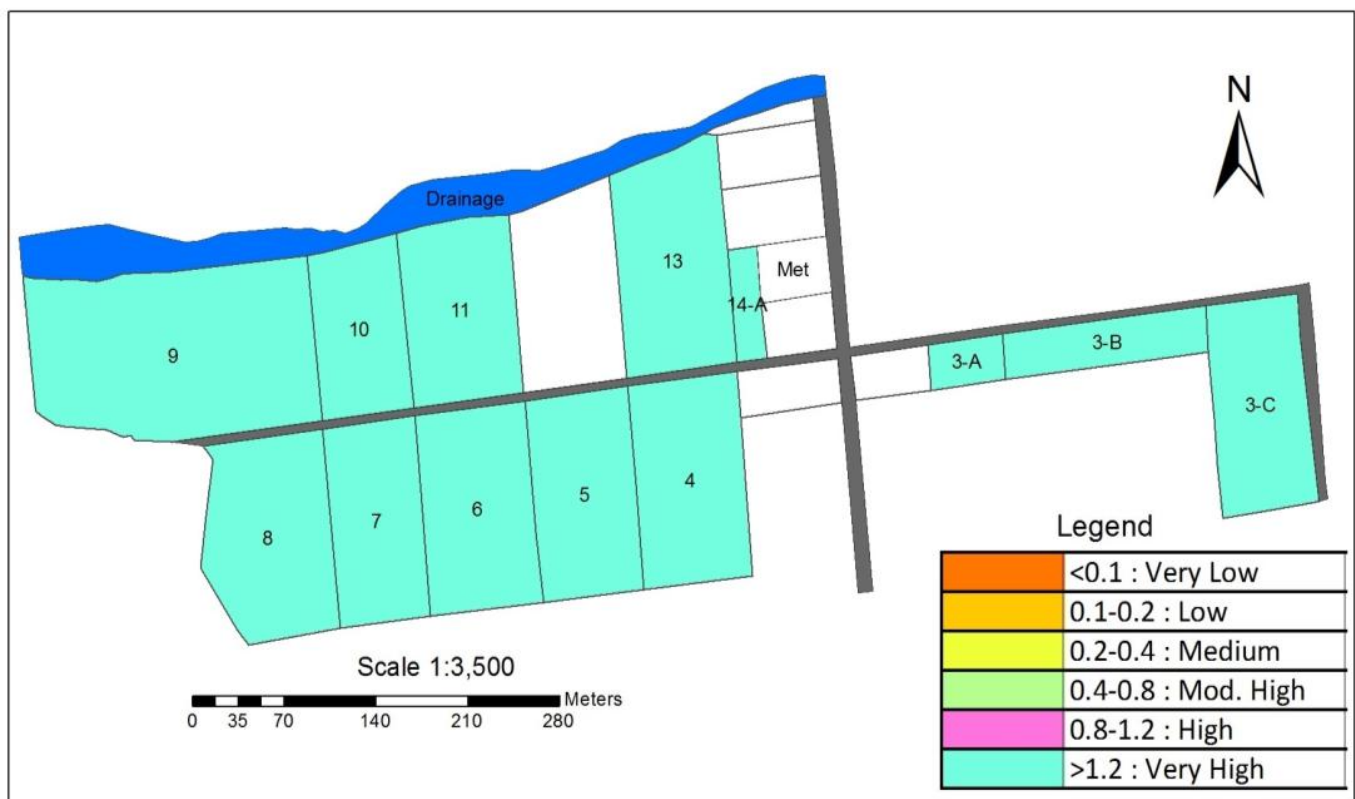

Map 14. GPS based soil copper map of organic farm, A.C,Pune (mg/kg). 
Fig.5\&6 GPS based soil available Zn map and GPS based soil available B map

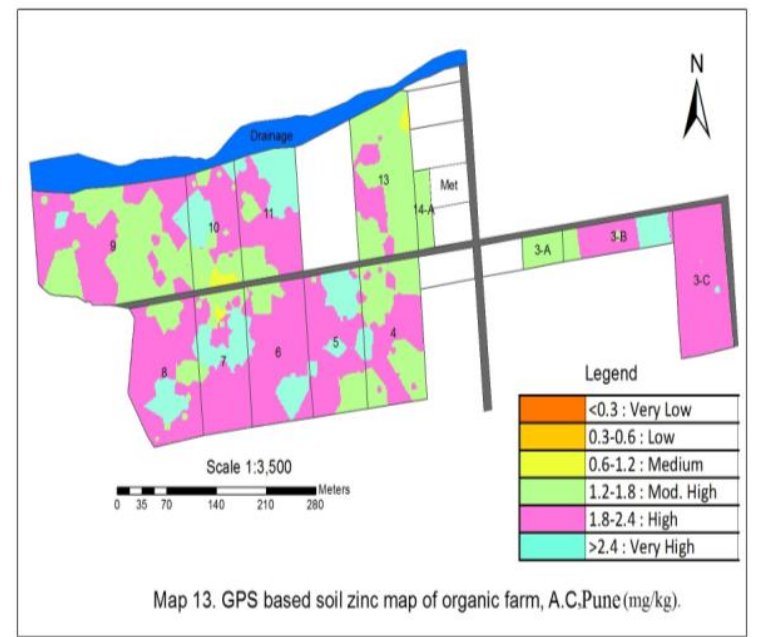

The similar observations have been reported by Meena (2009) in Central Research Farm, Central Campus, MPKV, and Rahuri. The sufficiency of available Mn might be due to high organic matter content and optimum soil moisture content.

The available copper in soils of organic farm was ranged from 3.36 to $7.64 \mathrm{mg} \mathrm{kg}^{-1}$ with an average of $5.82 \mathrm{mg} \mathrm{kg}^{-1}$ (Table 2 and Fig. 4). All the soil samples collected from organic farm were sufficient in available copper, as the critical limit of available copper is $0.2 \mathrm{mg}$ $\mathrm{kg}^{-1}$ (Katyal and Randhava, 1983). The similar types of results were also found by Meena (2009) in Central Research Farm, Central Campus, MPKV, Rahuri. The sufficiency of available copper might be due to the high organic matter content and optimum soil moisture in soil. The available zinc in soils of organic farm was ranged from 1.06 to 3.68 mg kg-1 with an average of $1.93 \mathrm{mg} \mathrm{kg}{ }^{-1}$ (Table 2 and Fig. 5). Out of all the soil samples collected from organic farm were sufficient in available zinc, as the critical limit of available zinc is $0.6 \mathrm{mg} \mathrm{kg}$ (Katyal, 1985). Kharche et al., (2001) recorded the similar trends of DTPA extractable Zn status in soils of Nashik District in Maharashtra. The sufficiency in available zinc might be due to high organic matter content in soil, which

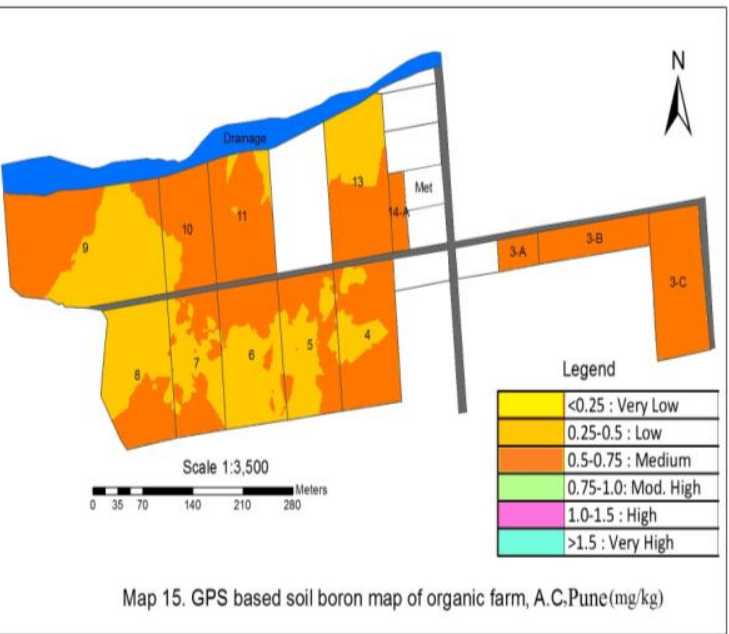

acts as natural chelating agent. The available boron in soils of organic farm of college of Agriculture, Pune ranges from 0.33 to 0.69 $\mathrm{mg} \mathrm{kg}$ with an average of $0.49 \mathrm{mg} \mathrm{kg}^{-1}$ (Table 2 and Fig. 6). Out of all the soil samples collected 56 per cent deficient and 44 per cent were sufficient in available boron, as the critical limit of available boron is $0.5 \mathrm{mg}$ $\mathrm{kg}^{-1}$. Sharma and Katyal (2006) reported that hot water soluble $\mathrm{B}$ in surface soils ranged from 0.07 to $3.62 \mathrm{mg} \mathrm{kg}^{-1}$. The deficiency of boron in soils might be due to higher content of $\mathrm{CaCO}_{3}$ and alkaline $\mathrm{pH}$ of soil.

\section{Correlation of available micronutrients with soil properties}

The $\mathrm{pH}$ was positively and non significantly correlated with $\mathrm{Cu}$ and $\mathrm{Zn}$ and negatively non significantly correlated with $\mathrm{Fe}, \mathrm{Mn}$ and $\mathrm{B}$. The similar results were also reported by Jadhav et al., (1978) in some citrus growing soils of Marathwada region in Maharashtra state (India) and found no significant relationship between available zinc and iron with soil $\mathrm{pH}$. The electrical conductivity showed negative and significant correlation with $\mathrm{Mn}$ which is evident by $\mathrm{r}$ value of $0.328^{*}$. Organic carbon showed positive and non significant correlation with available $\mathrm{Mn}$, $\mathrm{Zn}$ and $\mathrm{Cu}$. Minakshi et al., (2005) studied the 
spatial distribution of micronutrients in soils of Patiala District and reported that organic carbon is positively correlated with $\mathrm{Zn}, \mathrm{Cu}$ and $\mathrm{Mn}$. The $\mathrm{CaCO}_{3}$ was negatively and significantly correlated with available Fe and Mn which is evident by ' $r$ ' values of $0.170^{* *}$, and $-0.244^{*}$ respectively (Table 3 ).

\section{References}

Bingham, F.T. 1982. Boron, 9: 431-437, In: A.L. Page. edited. Methods of Soil analysis. Part 2. Agronomy, Am. Soc. Agron. Inc. Madisan, Wisconsin, USA.

Jadhav, N.S., Malewar, G.U. and Varade, S.B. 1978. Vertical distribution of zinc and iron in some citrus growing soils of Marathwada. $J$. Maharashtra Agric. Univ., 3(2):85-87.

Katariya, P. 2011. Characterization and classification of soils of water management project, MPKV, Rahuri. M.Sc. (Agri.) Thesis, Mahatma Phule Krishi Vidyapeeth Rahuri (Maharashtra) India.

Katyal, J.C. and Randhava, N.S. 1983. In Micronutrient FAO fertilizer and plant nutrition Katyal J.C.1985.Research achievement of all Indian Coordinate Scheme of micronutrient in soil and plants. J. Indian Soc. Soil. Sci., 52: 142-143.

Kharche, V.K., Patil, J.D. and Bulbule, A.V. 2001. Micronutrient status of soils of Nashik district, Maharashtra. National Seminar on development in soil science, No.2, pp161 Bull. Rome, 5: 92.

Lindsay, W.L. and Norwell, W.A. 1978. Developement of DTPA. soil test of $\mathrm{Zn}, \mathrm{Fe}$, Mn and Cu. Soil Sci. Soc. Am. J., 42(3): 421428.

Meena, S. 2009. Studies on physical and chemical properties of salt affected soils of central research farm, MPKV, Rahuri. M.Sc. (Agri.) Thesis, Mahatma Phule Krishi Vidyapeeth, Rahuri (Maharashtra) India.

Minakshi, N.S., Nayyar, U.K., Sharma, P.K. and Sood, A.K. 2005. Spatial distribution of micronutrients in soils of Patiala district. $J$. Indian Soc. Soil Sci., 53(3): 324-329.

Padole, V.R. and Mahajan, S.B. 2003. Status and release behavior of potassium in SwellShrink soils of Vidarbha, Maharashtra, $J$. Maharashtra Agric. Univ., 28(1): 3-7.

Page, A.L., Millar, R.H. and Keeney, D.R. 1982. Methods of Soil Analysis. Part. II. Chemical and Microbiological Properties. $2^{\text {nd }}$ Edition, ASA-SSSA, Madison, USA.

Sharma, B.D. and Katyal, J.K. 2006. Water soluble boron in benchmark soils in India and their relationship with soil properties. $J$. Indian Soc. Soil Sci., 54: 57-59.

Sharma, P.K. 2004. Emerging technology of remote sensing and GIS for the development of spatial data infrastructure. J. Indian Soc. Soil Sci., 52: 384- 406.

Sood, Anil, Sctia, R.K., Bansal, R.L., Sharma, P.K. and Nayyar, V.K. 2004. Spatial distribution of micro nutrients in soils of Amritsar district using frontier technology, held at Gurunanak dev university, Amritsar. Feb 7 to 9, 2004. pp Aiv-4.

Takkar, P.N., Chhibba, I.M. and Mehta, S.K. 1989. Twenty years of coordinated research om micronutrients in soils and plants. Bull. Indian Inst. Soil Sci., 1: 76.

Yadav, J.S.P. 2002. Conserving and managing water resources for sustainable agriculture. $J$. Water Manage., 10(1): 10-21.

Yeresheemi, A.N., Channal, H.T. Potagundi, M.S. and Satyanarayana, T. 1997. Salt affected soils of Upper Krishna Command, Karnataka. Agropedol., 7: 33-39.

\section{How to cite this article:}

Vivekananda Aich, N.B. More, Shiva Kumar Udayana and Patil, G.D. 2017. GPS-GIS Based Soil Maps of Micronutrients Status in Organic Farms at College of Agriculture, Pune (M.S.). Int.J.Curr.Microbiol.App.Sci. 6(8): 855-861. doi: https://doi.org/10.20546/ijcmas.2017.608.108 